\title{
THE DETERMINATION OF HEALTH SERVICES VOCATIONAL SCHOOL STUDENTS' KNOWLEDGE LEVELS ABOUT THE EFFECTS OF RADIATION ON HEALTH
}

\author{
Sağlık Hizmetleri Meslek Yüksekokulu Öğrencilerinin Radyasyonun Sağlık Üzerindeki
} Etkileri Hakkında Bilgi Düzeylerinin Belirlenmesi

Zehra Deniz ÇIRAK (D) Gülsüm YETIŞ̧ (D) Perihan GÜRBÜZ (D) Turgay KOLAÇ (D) İn̈nü Üniversitesi Sağlık Hizmetleri Meslek Yüksekokulu, Malatya

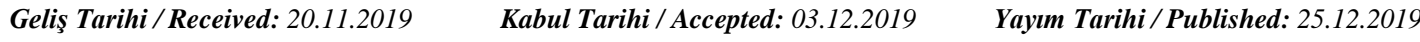

\begin{abstract}
Radiation is the energy emitted from atomic nuclei when passing to steady state. People are exposed to radiation from many different sources. This research was carried out to determine the students' knowledge levels about the effects of radiation on health. This descriptive research was conducted by using 'questionnaire application method' with 351 students of Health Services Vocational School. The statistical analysis of the data was done by using descriptive statistics and chi-square analysis.

Medical Imaging Program students' answering ratios to the statements; 'Radiation causes headache by damaging brain cells' $(86.0 \%)$, 'Radiation emitting devices disrupt people's psychology' $(75.0 \%)$ and 'Cell phones have serious negative impacts on health' $(68.0 \%)$ as 'yes' were statistically different from other students. The students who stated to take necessary precautions against radiation were determined; not to bring mobile phone in the bedroom $(81.1 \%)$, to keep radiation emitting devices away from head while asleep $(61.1 \%)$, not to use mobile phone while it is charged $(55.2 \%)$, to use laptops away from body $(58.3 \%)$ in higher ratios.

It has been determined that the radiation knowledge level of the students taking health education is not sufficient. In this regard, it would be beneficial to make arrangements in their curricula.
\end{abstract}

Keywords: Radiation, health, knowledge level

\section{ÖZ}

Radyasyon, sürekli duruma geçerken atom çekirdeğinden yayılan enerjidir. İnsanlar birçok farklı kaynaktan radyasyona maruz kalmaktadır. Bu araştırma, radyasyonun sağlık üzerindeki etkileri konusunda öğrencilerin bilgi düzeylerini belirlemek amacıyla yapılmıştır. Bu tanımlayıcı araştırma, 351 Sağlık Hizmetleri Meslek Yüksekokulu öğrencisi ile "anket başvuru yöntemi" ile gerçekleştirilmiştir. Verilerin istatistiksel analizi betimleyici istatistikler ve ki-kare analizi kullanılarak yapılmıştır.

Tıbbi Görüntüleme Programı öğrencilerinin; 'Radyasyon beyin hücrelerine zarar vererek baş ağrısına yol açar' (\% 86.0), 'Radyasyon yayan cihazlar insanların psikolojisini bozar' (\% 75.0) ve 'Cep telefonlarının sağlık üzerinde ciddi olumsuz etkileri vardır' (\% 68.0) ifadelerini 'evet' olarak yanıtlama oranları diğer öğrencilerden istatistiksel olarak farklıydı. Radyasyona karşı gerekli önlemleri aldığını belirten öğrencilerin daha yüksek oranlarda; cep telefonunu yatak odasına getirmedikleri (\% 81.1), radyasyon yayan cihazları uykuda iken başlarından uzak tuttukları (\% 61.1), şarj edilirken cep telefonunu kullanmadıkları ( $\%$ 55.2), dizüstü bilgisayarları vücuttan uzak tuttukları (\% 58.3) belirlendi.

Sağlık eğitimi alan öğrencilerin radyasyon bilgisi düzeyinin yeterli olmadığı belirlenmiştir. Bu bakımdan, müfredatlarında düzenlemelerin yapılması yararlı olacaktır.

Anahtar Kelimeler: Radyasyon, sağlık, bilgi düzeyi 


\section{INTRODUCTION}

When an atomic nucleus emits energy in the form of electromagnetic waves or particles, during passing from an unstable state to a more stable form, it is called radiation (Kiang \& Olabisi, 2019; Molu, Kahyaoğlu, \& Köksal, 2016; Yaren \& Radyasyon, 2005). Radiation is in our natural habitat and every living being is exposed to radiation from natural and / or technological sources in the environment (Brenner et al., 2003; Çınar, Çetin, Kalender, \& Bağcivan, 2015; Sont et al., 2001).

Sun rays, radio waves that enable radio and television communication, radiofrequency waves emitted from mobile phones, waves emitted by devices used for diagnosis and treatment in health field, $\mathrm{x}$-rays used in industry constitute part of the radiation sources which effect our daily lives (Bauer, Janßen, Schmitz, \& Ott, 2017; Bijwaard et al., 2017; Daroit, Visioli, Magnusson, Vieira, \& Rados, 2015; Kaya, Adapınar, \& Özkan, 1997).

It is important to be aware of the radiation hazards of devices that can not be given up to be used in the technological world. Radiation is examined in two groups as ionizing and nonionizing radiation. Radiation has negative effects on all living organisms (Goodman, Copplestone, Laptev, Gashchak, \& Auld, 2019; Molu et al., 2016; Seawright et al., 2019; Zarei, Vahab, Oryadi-Zanjani, Alighanbari, \& Mortazavi, 2019). These adverse effects are related to the dose of radiation exposed and the duration of exposure. Prolonged ionizing radiation exposure above 50-100 'mieSievert $(\mathrm{mSv})$ or acute ionizing radiation exposure above 10-50 $\mathrm{mSv}$ have been shown to have adverse effects on the human population (Brenner et al., 2003; Daşdağ, 2010; Jacob, Vivian, \& Steel, 2004).

Chronic effects of long-term low-dose radiation exposure in the life span has been determined to cause non-neoplastic diseases in many different systems as developmental disorders, intrauterine period anomalies, cataracts and sterility, as well as malignancies. Studies have shown that radiation exposure causes DNA damage and is a risk factor for many cancers as leukemia, lymphoma, lung, bone, liver and kidney cancers (Behjati et al., 2016; Jacob et al., 2004; Kiang \& Olabisi, 2019). Also, exposed radiation dose has been shown to increase all causes of death (Kiang \& Olabisi, 2019; Seawright et al., 2019; Zarei et al., 2019). Besides, short-term high-dose radiation exposure causes vomiting, hematopoietic system suppression, hair loss, tissue / organ bleeding and infections (Daşdağ, 2010; Osovets, Azizova, Day, Wald, \& Moseeva, 2012; Waselenko et al., 2004).

Radiation has no harmless threshold dose value, radiation-containing devices have become a part of our lives (Kiang \& Olabisi, 2019). Therefore, awareness about the effects of 
radiation and the ways of protection has been gaining importance day by day (Bolus, 2001; Brenner et al., 2003; Jacob et al., 2004; Shiralkar et al., 2003). Considering that young people are more exposed to radiation, it is important to determine and raise awareness of the Vocational School of Health Services students' knowledge levels about the effects of radiation on health.

\section{METHODS}

The aim of this research was to determine the knowledge levels of; First and Emergency Aid, Pharmacy Services, Medical Imaging Techniques, Child Development, Medical Laboratory Techniques, Medical Documentation and Secretarial, Oral and Dental Health, Home Patient Care programs students about radiations effect on health and to compare the Medical Imaging Techniques Program students' knowledge levels (who have courses on radiation in their education curriculum) with the stated program students.

The universe of this descriptive research consisted of 480 students who were actively taking education in Vocational School of Health Services in 2016-2017 academic years. In the research, it was aimed to reach the whole universe without using a sample selection method. However, those who refused to participate in the research and who did not attend to school at the time of the research were excluded from the research. After the exclusion of the forms with missing data, the research was completed with a sample of 351 students.

At the beginning of the research, written permissions from Malatya Clinical Research Ethics Committee (2018/6-7), Health Services Vocational School in which the research was performed and informed consent of the students who were participating in the research on a voluntary basis were obtained. In the research; a questionnaire prepared by the researchers using the literature information was used. Survey form consists of 42 questions including; 8 questions about socio-demographic characteristics of the students, 8 questions about their opinion on the effects of radiation on health and 26 questions about their information level on radiation.

The data were collected by using questionnaires in the classroom environment during the extracurricular hours. The questionnaires were completed by the students in 5-10 minutes and the completed forms were collected by the researchers. Statistical analysis of the data was performed with SPSS program by using descriptive statistics (number, percentage, mean, standard deviation) and chi-square analysis. Results were evaluated at $95 \%$ confidence interval and $\mathrm{p}<0.05$ significance level. 


\section{RESULTS}

$70.9 \%$ of the students $(\mathrm{n}=351)$ were girls and the mean age was $19.70 \pm 1.94 .67 .0 \%$ of the students were in the first year of their education. Of the students who performed in the research; $21.9 \%$ (77) was from First and Emergency Aid program, 15.7\% (55) was from Pharmacy Services program, 14.2\% (50) was from Medical Imaging Techniques program, $13.4 \%$ (47) was from Child Development program, 13.1\% (46) was from Medical Laboratory Techniques program, 9.4\% (33) was from Medical Documentation and Secretariat program, $8.0 \%$ (28) was from Oral and Dental Health program and 4.3\% (15) was from Home Patient Care program (Figure 1).

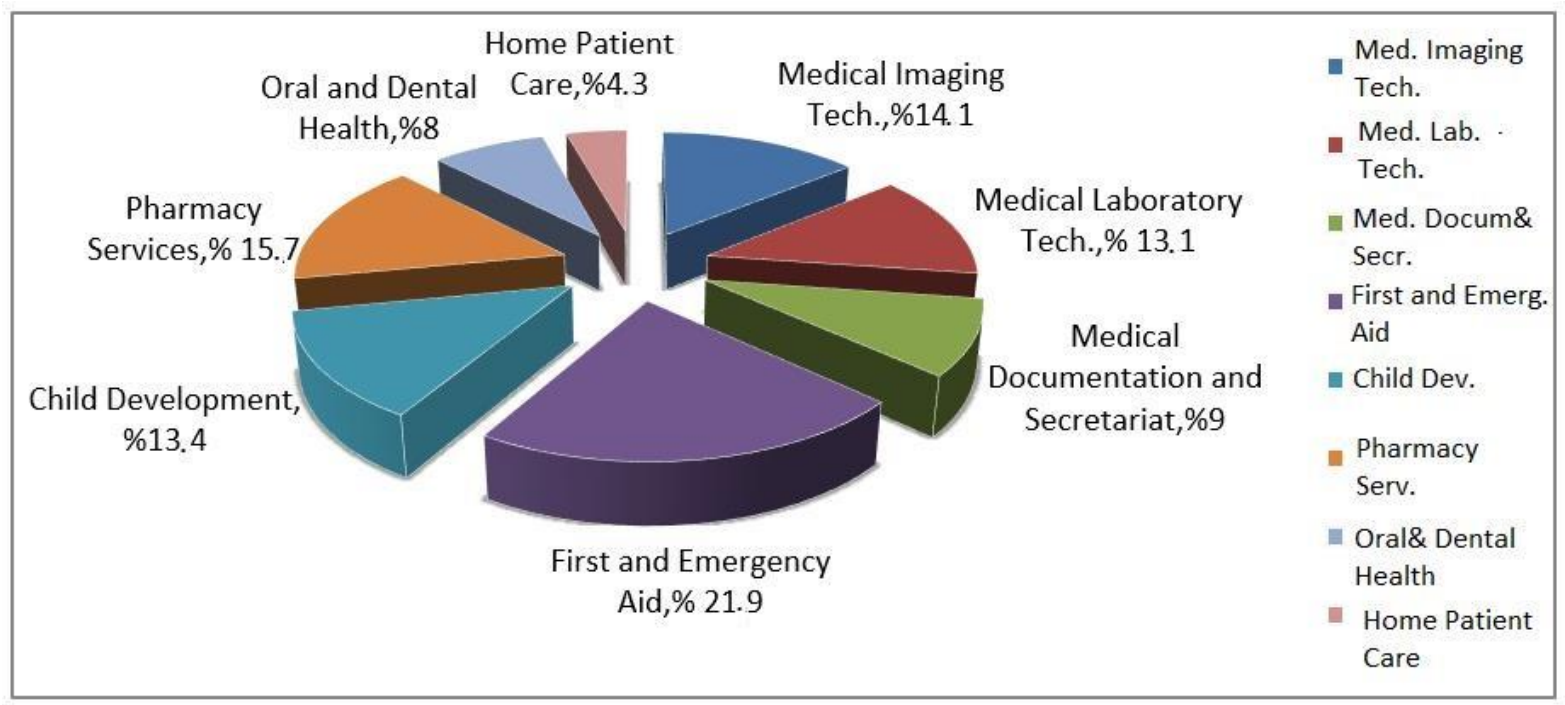

Figure 1. Percentage of programs of the students who attended the research

When the answers of the students to the statements; 'Radiation increases the risk of cancer by weakening the immune system', 'Radiation causes headache by damaging brain cells', 'Exposure to radiation can cause abortion' were analyzed, the answers were found to be as 'yes' in similar proportions of $94.6 \%, 94 \%, 95.1 \%$ in order (Table 1). In addition, the sentences which were defining the harmful effects of radiation on other living beings; 'Radiation has negative effects on other living beings besides humans' and 'Radiationemitting vehicles damage the vegetation' were answered as 'yes' by the rates of $91.1 \%$ and $85.1 \%$ in order. It was found that $71.6 \%$ of the respondents stated that 'Radiation-emitting vehicles cause regional climate change'.

Table 1: Students' answers to the statements about radiation

\begin{tabular}{cc|c|c|c}
\hline & Yes & No \\
\cline { 2 - 5 } Answer the following statements based on your own thoughts & $\#$ & $\mathbf{\%}$ & $\#$ & \% \\
\hline a. Radiation increases the risk of cancer by weakening the immune system & 332 & 94.6 & 19 & 5.4 \\
\hline
\end{tabular}


The Determination of Health Services Vocational School Students' Knowledge Levels about the Effects of Radiation on Health Gülsüm YETİŞ, Zehra Deniz ÇIRAK, Perihan GÜRBÜZ, Turgay KOLAÇ

\begin{tabular}{lllll}
\hline b. Radiation causes headache by damaging brain cells & 328 & 94.0 & 21 & 6.0 \\
\hline c. Radiation-emitting devices disrupt people's psychology & 210 & 60.7 & 136 & 39.3 \\
\hline d. Mobile phones seriously affect human health in a negative manner & 277 & 79.1 & 73 & 20.9 \\
\hline e. Radiation emitting vehicles cause regional climate change & 249 & 71.6 & 99 & 28.4 \\
\hline f. Radiation-emitting vehicles damage the vegetation & 297 & 85.1 & 52 & 14.9 \\
\hline g. Exposure to radiation can cause abortion & 212 & 95.1 & 11 & 4.9 \\
\hline h. Radiation has negative effects on other living beings besides humans & 205 & 91.1 & 20 & 8.9 \\
\hline
\end{tabular}

Table 2 compares the students' answers about radiation according to their educational status in the Medical Imaging Program and other programs. Medical Imaging Program students answering ratios to the statements; 'Radiation causes headache by damaging brain cells' (86.0\%), 'Radiation emitting devices disrupt people's psychology' (75.0\%) and 'Cell phones seriously affect human health' $(68.0 \%)$ as 'yes' was found to be statistically significantly higher than other students $(\mathrm{p}<0.05)$.

Although it is not statistically significant ( $p>0.05)$, Medical Imaging Program students answered the statements; 'Radiation increases the risk of cancer by weakening the immune system'(92.0\%) and 'Radiation-emitting vehicles cause regional climate change' $(61.2 \%)$ as 'yes' in higher ratios ( Table 2).

Table 2: The comparison of the answers given to the statements about radiation by the students of the Medical Imaging Program and other programs

\begin{tabular}{|c|c|c|c|c|c|c|}
\hline \multirow[t]{2}{*}{ Statements about radiation } & \multirow[t]{2}{*}{ Answer } & \multicolumn{2}{|c|}{$\begin{array}{l}\text { Medical } \\
\text { Imaging } \\
\text { Techniques } \\
\text { Students }\end{array}$} & \multicolumn{2}{|c|}{$\begin{array}{l}\text { Students of the } \\
\text { Other Programs }\end{array}$} & \multirow[t]{2}{*}{ Significance } \\
\hline & & $\mathrm{S}$ & $\%$ & S & $\%$ & \\
\hline \multirow{2}{*}{$\begin{array}{l}\text { Radiation increases the risk of cancer by } \\
\text { weakening the immune system }\end{array}$} & Yes & 46 & 92.0 & 270 & 89.9 & $X 2=0.76$ \\
\hline & No & 4 & 8.0 & 31 & 10.1 & $\mathrm{p}=0.279$ \\
\hline \multirow{2}{*}{$\begin{array}{l}\text { Radiation causes headache by damaging } \\
\text { brain cells }\end{array}$} & Yes & 43 & 86.0 & 252 & 84.3 & $X 2=6.57$ \\
\hline & No & 7 & 14.0 & 47 & 15.7 & $\mathrm{p}=0.019$ \\
\hline \multirow{2}{*}{$\begin{array}{l}\text { Radiation-emitting devices disrupt people's } \\
\text { psychology }\end{array}$} & Yes & 36 & 75.0 & 198 & 66.4 & $\mathrm{X} 2=29.76$ \\
\hline & No & 12 & 25.0 & 100 & 33.6 & $\mathrm{p}=0.000$ \\
\hline \multirow{2}{*}{$\begin{array}{l}\text { Mobile phones seriously affect human health } \\
\text { in a negative manner }\end{array}$} & Yes & 34 & 68.0 & 196 & 65.4 & $X 2=4.38$ \\
\hline & No & 16 & 32.0 & 103 & 34.6 & $\mathrm{p}=0.032$ \\
\hline \multirow{2}{*}{$\begin{array}{l}\text { Radiation emitting vehicles cause regional } \\
\text { climate change }\end{array}$} & Yes & 30 & 61.2 & 180 & 60.3 & $\mathrm{X} 2=2.98$ \\
\hline & No & 19 & 38.8 & 119 & 39.7 & $\mathrm{p}=0.062$ \\
\hline \multirow{2}{*}{$\begin{array}{l}\text { Radiation-emitting } \\
\text { vegetation }\end{array}$} & Yes & 42 & 84.0 & 255 & 85.3 & $X 2=0.05$ \\
\hline & No & 8 & 16.0 & 44 & 14.7 & $\mathrm{p}=0.477$ \\
\hline
\end{tabular}

The answering ratio of the statement 'Radiation-emitting vehicles damage the vegetation' was close to each other and this rate was statistically insignificant ( $p>0.05)$.

The students who said 'yes' to the statement 'I take necessary precautions to be protected against radiation' were determined; not to bring their mobile phone in the bedroom $(81.1 \%)$, to keep devices such as mobile phones and computers away from head while asleep $(61.1 \%)$, not to use their mobile phone while it is charged (55.2\%), to use laptops away from their body 
$(58.3 \%)$ in higher ratios. These behaviors were found to be statistically significant $(\mathrm{p}<0.05)$

(Table 3).

In addition, students who stated to take necessary precautions to be protected against radiation were found to think that microwave oven should not be used because of it's radiation emitting feature $(52.5 \%)$ and this was statistically significant $(\mathrm{p}<0.05)$. However, they were found to disagree to the statements of 'hair dryer (57.1\%) and air conditioner $(56.4 \%)$ should not be used because of their radiation emitting effects', in a statistically significant manner $(\mathrm{p}<0.05)$ (Table 3$)$.

Table 3: Comparison of students' answers to radiation related statements according to their statements about taking necessary precautions to be protected against radiation

\begin{tabular}{|c|c|c|c|c|c|c|}
\hline & \multicolumn{6}{|c|}{ I take necessary precautions to be protected against radiation } \\
\hline & \multirow[t]{2}{*}{ Answer } & \multirow{2}{*}{ Yes } & \multicolumn{3}{|c|}{ No } & \multirow[t]{2}{*}{ significance } \\
\hline & & & $\%$ & \# & $\%$ & \\
\hline \multirow{2}{*}{$\begin{array}{l}\text { I do not bring my mobile phone in the } \\
\text { bedroom }\end{array}$} & Yes & 31 & 18.9 & 15 & 8.2 & $X^{2}=8.73$ \\
\hline & No & 133 & 81.1 & 169 & 91.8 & $\mathrm{p}=0.002$ \\
\hline \multirow{2}{*}{$\begin{array}{l}\text { I keep devices such as mobile phones and } \\
\text { computers away from my head while I sleep }\end{array}$} & Yes & 99 & 61.1 & 62 & 33.7 & $X^{2}=26.02$ \\
\hline & No & 63 & 38.9 & 122 & 66.3 & $\mathrm{p}=0.000$ \\
\hline \multirow{2}{*}{$\begin{array}{l}\text { I do not use my mobile phone while it is } \\
\text { charged }\end{array}$} & Yes & 90 & 55.2 & 52 & 28.4 & $X^{2}=25.58$ \\
\hline & No & 73 & 44.8 & 131 & 71.6 & $\mathrm{p}=0.000$ \\
\hline \multirow[t]{2}{*}{ I use laptops away from my body } & Yes & 95 & 58.3 & 68 & 37.2 & $\mathrm{X}^{2}=15.43$ \\
\hline & No & 68 & 41.7 & 115 & 62.8 & $\mathrm{p}=0.000$ \\
\hline \multirow{2}{*}{$\begin{array}{l}\text { Microwave should not be used as it emits } \\
\text { radiation }\end{array}$} & Yes & 85 & 52.5 & 70 & 38.0 & $X^{2}=7.25$ \\
\hline & No & 77 & 47.5 & 114 & 62.0 & $\mathrm{p}=0.005$ \\
\hline \multirow{2}{*}{$\begin{array}{l}\text { Hair dryer should not be used as it emits } \\
\text { radiation }\end{array}$} & Yes & 69 & 42.9 & 52 & 28.3 & $X^{2}=8.03$ \\
\hline & No & 92 & 57.1 & 132 & 71.7 & $\mathrm{p}=0.003$ \\
\hline \multirow{2}{*}{$\begin{array}{l}\text { Air conditioning should not be used as it } \\
\text { emits radiation }\end{array}$} & Yes & 71 & 43.6 & 49 & 26.6 & $X^{2}=10.94$ \\
\hline & No & 92 & 56.4 & 135 & 73.4 & $\mathrm{p}=0.001$ \\
\hline \multirow{2}{*}{$\begin{array}{l}\text { I try to stay away from all radiation emitting } \\
\text { vehicles }\end{array}$} & Yes & 96 & 59.3 & 52 & 28.6 & $X^{2}=32.92$ \\
\hline & $\mathrm{No}$ & 66 & 40.7 & 130 & 71.4 & $\mathrm{p}=0.000$ \\
\hline \multirow{2}{*}{$\begin{array}{l}\text { I constantly warn my environment about the } \\
\text { damages of radiation }\end{array}$} & Yes & 92 & 57.1 & 48 & 26.1 & $X^{2}=34.34$ \\
\hline & No & 69 & 42.9 & 136 & 73.9 & $\mathrm{p}=0.005$ \\
\hline
\end{tabular}

The students who said 'yes' to the 'I take necessary precautions to be protected against radiation' statement were determined to; try to stay away from all radiation-emitting vehicles (\%59.3) and constantly warn their environment about the damages of radiation (\%57.1) in significantly higher ratio $(\mathrm{p}<0.05)$ (Table 3$)$.

\section{DISCUSSION}

In daily lives, people are exposed to radiation due to many natural (cosmic, earth) and human made (technological products such as mobile phones, medical imaging devices) factors. Safe radiation exposure is only possible through training and increased awareness about radiation. The media and educational institutions should undertake important tasks on 
this topic. In this research, questions about general radiation knowledge were asked to the Health Services Vocational School students, in order to compare the radiation knowledge level among students who took education about radiation and who did not. Medical Imaging Techniques students' level of knowledge about radiation was found to be better than other students. Yalçın et al. also had investigated teachers 'attitudes towards radiation and found that science-technology and mathematics teachers' attitudes towards radiation concept were positively higher than other branch teachers (Yalçın, Karenoğulları, \& Yalçın, 2018). It is thought that this situation depends on the received theoretical education and may be related to the curriculum. In a recent study that determined the patients' knowledge level about the harmful effects of radiation, $76 \%$ of the population, most of whom were older than 45 years and were primary school graduates, stated that radiation had harmful effects (Güdük, K1lıç, \& Güdük, 2018). Koçyiğit et al. (2014), in a study conducted with assistant physicians, medical school students, nurses and 250 participants working in a university hospital, has determined the students to have better knowledge levels about radiation. They have explained this result by recent and updated education (Koçyiğit et al., 2014). In this research, high awareness about radiation hazards may be due to the fact that the research has been done with the young population receiving university education.

Medical Imaging Program students' statements about the negative effects of radiation on human health are significantly different from the other students and this result is similar to the study of Sarı̈öz et al. (Sarı̈öz, Karakuş, \& İrak, 2012). Yücel et al., in a study conducted with patients of whom most of them were primary school graduates and were waiting for radiological examination, has determined the ratio of cancer and radiation correlation to be known as $57.78 \pm 19.87$. The ratio was found to increase with educational level (Yücel et al., 2009). In this research, the answering ratio to the statement 'Exposure to radiation can cause abortion' as 'yes' has been determined to be higher than; Ağbulut and Oktay's study with high school students $(68.9 \%)$ and their parents $(72.8 \%)$, and another study with patients (33.5\%) (Ağbulut \& Oktay, 2017; Yücel et al., 2009). This difference may be due to the fact that the sample group of the research is studying in the health field. The answer to the statement about usage of laptops away from their body (58.3\%) is similar with Sarıgöz et al's study (Sarıgöz et al., 2012). In the research, although the students stated that microwave oven should not be used because of it's radiation emitment, the same answer was not taken in the statements about hair dryer and air conditioner usage. These results point out that the students' awareness about radiation emitting devices may be confusing. Also, the students who indicated to take necessary precautions to be protected against radiation, stated that they 
tried to stay away from all radiation-emitting vehicles (\%59.3) and they constantly warned their environment about the damages of radiation (\%57.1). This is a positive point about the social responsibility status of the students.

In the research, when compared to other subjects, awareness of the effect of radiation on climate and vegetation was lower in all students. This result is similar to that of Sarigöz et al.'s study (Sarı̈öz et al., 2012). It is seen that social awareness is not sufficient and awareness should be increased on these issues. The students should be educated about radiation in the curriculum, and after graduation, they should be provided with up-to-date information in order to refresh their knowledge through in-service training programs. At the same time, it is obvious that the media are effective in providing and sharing information on radiation protection and radiation safety. Seminars, programs and brochures can be prepared and shared through the media about radiation.

\section{REFERENCES}

Ağbulut H, Oktay M. Radyasyonun taşınması ve yayılımı hakkında öğrencilerin ve halkın görüşleri nelerdir? Marm Üni Ata Ĕ̆ Fak Ĕ̆ Bil Der, 2017;44:1-13. [CrossRef]

Bauer S, Marco J, Martin S, Günter O. Mathematical modeling of optical radiation emission as a function of welding power during gas shielded metal arc welding, Heal phy, 2017;113:335-346. [CrossRef]

Behjati S, Gundem G, Wedge DC, et al. Mutational signatures of ionizing radiation in second malignancies, Nat com, 2016;7:1-8. [CrossRef]

Bijwaard H, Vries G, J.Scheurleer J, et al. Compliance to Diagnostic Reference Levels for radiation exposure in common radiological procedures in Dutch hospitals: A nation-wide survey carried out by medical imaging students, Radiogr, 2017;23:197-201. [CrossRef]

Bolus NE. Basic review of radiation biology and terminology, J nuc med tech, 2001;29:67-73. [CrossRef]

Brenner DJ, Doll R, Goodhead TD, et al. Cancer risks attributable to low doses of ionizing radiation: assessing what we really know, PNAS, 2003;100:13761-13766. [CrossRef]

Çınar Fİ, Çetin FŞ, Kalender N, Bağcivan G. Hemşirelik yüksekokulu öğrencilerinin güneşten korunmaya ilişskin davranışlarının belirlenmesi, Gülh Tip Derg, 2015;57:241-246. [CrossRef]

Daroit NB, Visioli F, Magnusson AS, Vieira Gr, Rados PV. Cell phone radiation effects on cytogenetic abnormalities of oral mucosal cells, Bra or res, 2015;29. [CrossRef]

Daşdağ S. İyonlaş̧tırıcı radyasyonlar ve kanser, Dicle T Der, 2010;37:177-185.

Goodman J, Copplestone D, Laptev GV, Gashchak S, Auld KJRS. Variation in chronic radiation exposure does not drive life history divergence among Daphnia populations across the Chernobyl Exclusion Zone, Eco Ev, 2019;9:2640-2650. [CrossRef]

Güdük Ö, Kıllı̧ CH, Güdük Ö. Radyasyonun Zararli Etkileri Hakkinda Hastalarin Bilgi Düzeyinin Değerlendirilmesi: Bir Hastane Örneği, Adly Ün Să̆ Bil Der, 2018;4:874-889. [CrossRef]

Jacob K, Vivian G, Steel J. X-ray dose training: are we exposed to enough? Cl rad, 2004;59:928-934. [CrossRef] 
Kaya T, Adapınar B, Özkan Y. Temel radyoloji tekniği, Nobel Kitabevi, İstanbul, 1997.

Kiang JG, Olabisi AO. Radiation: a poly-traumatic hit leading to multi-organ injury, Cell \& Biosci, 2019;9:25. [CrossRef]

Koçyiğit A, Kaya F, Çetin T, et al. Radyolojik tetkikler sırasında maruz kalınan radyasyon hakkında să̆lık personelinin bilgi düzeyleri, Pam T Der, 2014;7:137-142. [CrossRef]

Molu Z, Kahyaoğlu H, Köksal EA. Fen Bilgisi Öğretmen Adaylarının Radyoaktiflikle İlgili Bilgi Düzeyleri, JOTCSC, 2016;1:165-190. [CrossRef]

Osovets S, Azizova TV, Day RD, Wald N, Moseeva MB. Direct and indirect tasks on assessment of dose and time distributions and thresholds of acute radiation exposure, Hea phy, 2012;102:182-195. [CrossRef]

Sarıg̈̈z O, Karakuş A, İak K. Meslek yüksekokulu ögrencilerinin elektromanyetik kirlilik ile ilgili görüşlerinin değerlendirilmesi, Ejovoc (Electronic Journal of Vocational Colleges), 2012;2:1-8. [CrossRef]

Seawright JW, Sridharan V, Landes RD, et al. Effects of low-dose oxygen ions and protons on cardiac function and structure in male C57BL/6J mice, Li Sci Sp Res, 2019; 20:72-84. [CrossRef]

Shiralkar S, Rennie A, Snow M, Galland RB, Lewis MH, Gower-Thomas K. Doctors' knowledge of radiation exposure: questionnaire study, Bmj, 2003;327:371-372. [CrossRef]

Sont WN, Zielinski JM, Ashmoreet JP, et al. First analysis of cancer incidence and occupational radiation exposure based on the National Dose Registry of Canada, Am J Epid, 2001;154:309-318. [CrossRef]

Waselenko JK, MacVittie TJ, Blakely WF, et al. Medical management of the acute radiation syndrome: recommendations of the Strategic National Stockpile Radiation Working Group, A int med, 2004;140: 1037-1051.

Yalçın P, Karenoğulları T, Yalçın SA. Öğretmenlerin Radyasyon Kavramına Karşı Tutum ve Bilgilerinin Değerlendirilmesi, Ĕ B Bil, 2018;43:245-260. [CrossRef]

Yaren H, Karayilanoğlu T. Radyasyon ve insan să̆ll̆̆g üzerine etkileri, TSK Kor Hek Bült, 2005;4:199-208. [CrossRef]

Yücel A, Karakas E, Bulbul E, Kocar İ, Duman B, Onur A. Knowledge about ionizing radiation and radiation protection among patients awaiting radiological examinations: a cross-sectional survey, Koc $T$ Der, 2009; 10:25-31. [CrossRef]

Zarei S, Vahab M, Oryadi-Zanjani MM, Alighanbari N, Mortazavi SMJ. Mother's Exposure to Electromagnetic Fields before and during Pregnancy is Associated with Risk of Speech Problems in Offspring, J biomed phy \& eng, 2019;9:61. 